\section{An older profession yet}

\author{
Stephen Hancocks OBE \\ Editor-in-Chief
}

Send your comments to the

Editor-in-Chief,

British Dental Journal

64 Wimpole Street,

London

W1G 8YS

Email bdj@bda.org
Prostitution has been given the epithet of the oldest profession in the world. Quite who bestowed this accolade I have been unable to discover but it is doubtless one of those givens to which we must all subscribe, the title that is, not necessarily the service.

However, despite the wisdom of our predecessors I wish to dispute the chronology of the title. When offering a service, or a product, one has first to attract potential clients, customers or patients and in order to be successful one has to advertise one's wares. So, it is my contention that, if we are to accept that prostitution is a profession, then we have to accept that the profession of advertising preceded it and is older still; else the market would never have flourished.

Already sensing the fears of respectable readers as to where this line of thought might be leading, I should state before too much longer that it is connected with the General Dental Council's (GDC) new guidance on advertising, which comes into effect on 1 March 2012. ${ }^{1}$ Again, in deference to readers' sensibilities I would point out that the focus here is on advertising and not on drawing any other parallels at all.

Given that advertising is such a way of life to us now, it is difficult to remember that it is a relatively small number of years since the GDC relaxed its extremely tight restrictions on the dental profession not only advertising, which was a cardinal sin, but even meekly promoting itself in any way, shape or form. In retrospect it seems so very old-fashioned for the Council to have determined the size of brass plate that was allowable and that appearing in the media was hung about with so many ifs, buts and maybes that one hardly dare squeak in support of oral health for fear of being dragged to the dungeons.

\section{A RESPECTABLE REFERENCE}

Doubtless the thought behind it all was very laudable but the particulars belonged to a different age. In the new guidelines the over-riding sentiment in protecting the public is that all advertising should be legal, decent, honest and truthful, and in truth I do not believe that we would have it any other way. The guidance is a modest two pages in extent and is commendably brief but comprehensively pragmatic. Basically it states that we should none of us attempt to mislead the public into believing that we are anything we are not, nor that the service or services that we offer are beyond that which we can or are qualified to deliver. In essence, in a rather ironic way, it is an ethical stand for evidence-based promotion. This is no more than we would expect of services being offered to us, for whatever purpose. Does it do what it says? On what is this based? Can we see proof?

Lady Tippins, a character in Charles Dickens' Our Mutual Friend (an appropriate reference I think in this the 200th anniversary of the year of his birth) opines of a circumstance of one of the lines of the plot 'I assure you my dear Veneering, [coincidentally a name of singular or perhaps multiple appropriateness to our profession] that this is the oddest affair! Like the advertising people, I don't ask you to trust me without a respectable reference.' And here it is again in a nutshell, the human requirement for both trust and for word of mouth, for it is these which provide almost the entire foundation upon which good dental practice, successful business and, crucially, effective patient service is based.

This is such the case that the need for advertising in its rather more raw or commercially intrusive sense has, in fact, such a small part to play in our practising lives. It is wholly correct that the GDC lays down certain fundamentals as to what may or may not be claimed in order that the public is not bamboozled or deceived but these are common sense and decent standards to which only the very marginal few of us would not subscribe. Almost as an aside to this it should be noted that it was in the background to the new guidance that the issue of titles, and specifically the use of the courtesy title 'doctor' was raised to such furore. It would be wrong to let the matter pass without commenting on the elegant way in which this volatile issue has been addressed while still providing public protection. It is not only worth reading the new document, it is essential, for it also brings up to date guidance on website content as reflected in European requirements and in relation to requiring links to the GDC's website for the information of patients.

So, whether advertising is as old as the hills, or whatever other analogy you care to invoke, the reasons for bringing it up to speed with a modern ethic are compelling and important if we are to continue to maintain high standards in the areas of efficient practice management and thorough patient care.

1. General Dental Council. Principles of ethical advertising. London: GDC, 2012. www.gdc-uk.org

DOI: $10.1038 /$ sj.bdj.2012.145 